\title{
Implementasi Bauran Pemasaran Kepariwisataan Dalam Upaya Peningkatan Kunjungan Wisatawan
}

\author{
Imas Komariyah ${ }^{1}$, Darmawan Megananda Sunandar ${ }^{2}$ \\ ${ }^{1}$ Universitas Wanita Internasional, komariyahimas26@gmail.com \\ ${ }^{2}$ STIE Tidharma, darmawanms@gmail.com
}

\begin{abstract}
ABSTRAK
Jawa Barat dikenal sebagai provinsi yang memiliki potensi, baik potensi kekayaan alam, budaya, dan juga pariwisata. Salah satu potensi unggulan di wilayah Provinsi Jawa Barat atau Tatar Sunda adalah dimilikinya kekayaan dan keragaman sumber daya pariwisata yang tinggi, meliputi wisata alam, wisata budaya dan wisata minat khusus. Pariwisata merupakan salah satu potensi yang diandalkan sebagai sektor yang potensial untuk pembangunan Jawa Barat, berkaitan dengan alasan ekonomi, sosial, konservasi, serta pelestarian lingkungan dan budaya, kawasan pantai Pangandaran salah satu objek wisata yang menjadi primadona dalam wisata bahari di Jawa Barat bagian selatan. Penelitian ini bertujuan untuk mengkaji implementasi bauran pemasaran kepariwisataan dalam upaya peningkatkan kunjungan wisatawan pantai Pangandaran. Penelitian ini menggunakan single cash (studi kasus tunggal), dengan menggunakan metode kualitatif, data dikumpulkan melalui observasi, wawancara mendalam, dan dokumentasi, dengan tujuan untuk menghasilkan kesimpulan terbaik dan dapat memperkuat argumentasi peneliti. Dari hasil penelitian menunjukkan implementasi bauran pemasaran kepariwisataan yang meliputi produk, harga, distribusi, promosi, proses, karyawan, dan sarana prasarana belum dilaksanakan secara optimal, sehingga kunjungan wisatawan Pantai Pangandaran belum menunjukkan hasil yang optimal pula. Kurang optimalnya kunjungan wisatawan, ini disebabkan kemampuan pengelola wisata pantai Pangandaran dalam mengimplementasi bauran pemasaran kepariwisataan belum dilaksanakan secara profesional. Dari hasil penelitian dapat disimpulkan bahwa implementasi bauran pemasaran kepariwisataan dalam peningkatan kunjungan wisatawan secara keseluruhan bagi pihak pengelola dan pihak terkait perlu mempunyai komitmen yang jelas, Sumber Daya Manusia harus teruji kompetensinya, dan manajemen harus dilaksanakan secara terpadu dan terarah.
\end{abstract}

Kata Kunci: Bauran Pemasaran, Kunjungan Wisatawan, Pantai Pangandaran, Jawa Barat.

\begin{abstract}
West Java is known as a province that has the potential, both natural wealth potential, culture and tourism. One of the superior potentials in the area West Java Province or Tatar Sunda is the wealth and diversity of hight tourism resources, including natural tourism, cultural tourism and special interest tourism. Tourism is one potential that is relied on as a potential sector for the development of West Java, related to economic, social, conservation, and environmental and cultural preservation reasons, Pangandaran beach area, one of the tourism objects that is a strength in marine tourism in southern West Java. This study aims to examine the implementation of tourism marketing mix in an effort to increase tourist visits to Pangandaran beach. This research uses single cash (single case study), using qualitative methods, data is collected through observation, in-depth interviews, and documentation, with the aim to produce the best conclusions and can strengthen the researchers' arguments. From the results of the study showed that the implementation of the tourism marketing mix which includes products, prices, distribution, promotion, process, people, and pysical evidence has not been implemented optimally, so that tourists visiting Pangandaran Beach have not shown optimal results. Less optimal tourist visits, this is due to the ability of Pangandaran beach tourism managers to implement the tourism marketing mix has not been implemented professionally. From the results of the study it can be concluded that the implementation of tourism marketing mix in increasing tourist visits as a whole for the manager and related parties need to have a clear commitment, Human Resources must be tested for competence, and management of Pangandaran beach tourism management needs to be carried out in an integrated and directed manner.
\end{abstract}

Keywords: Tourism Marketing Mix, Tourist Visit, Pangandaran Beach, West Java.

Diterima: 1 Agustus 2018, Direvisi: 12 Januari 2019, Diterbitkan: 15 Agustus 2019 


\section{PENDAHULUAN}

Provinsi Jawa Barat sebagai daerah yang berbatasan langsung dengan ibu kota Negara, dituntut untuk dapat mengembangkan berbagai potensi yang dimilikinya agar mampu melaksanakan program pembangunan yang berkelanjutan dengan optimal menuju tercapainya visi sebagai provinsi termaju di Indonesia. Jawa Barat dikenal sebagai provinsi yang memiliki potensi, baik potensi kekayaan alam, budaya, dan juga pariwisata. Salah satu potensi unggulan di wilayah Provinsi Jawa Barat atau Tatar Sunda adalah dimilikinya kekayaan dan keragaman sumber daya pariwisata yang tinggi, meliputi wisata alam, wisata budaya dan wisata minat khusus. Pariwisata merupakan salah satu potensi yang diandalkan sebagai sektor yang potensial untuk pembangunan Jawa Barat, berkaitan dengan alasan ekonomi, sosial, konservasi, serta pelestarian lingkungan dan budaya.

Dalam kebijakan pariwisata di Jawa Barat disebutkan bahwa sektor pariwisata merupakan salah satu dari tujuh bidang unggulan yang menjadi ciri Jawa Barat sebagai provinsi termaju di Indonesia Tahun 2025, Undang-Undang Republik Indonesia No. 10 Tahun 2009, Tentang Kepariwisataan, "Daya tarik wisata dijelaskan sebagai sesuatu yang dimiliki keunikan, kemudahan, dan nilai yang berupa keanekaragaman kekayaan alam, budaya dan hasil buatan manusia yang menjadi sasaran atau kunjungan wisatawan.

Kawasan wisata Pangandaran sebagai objek wisata yang menjadi primadona dalam wisata bahari di Jawa Barat bagian selatan. saat ini, Pangandaran adalah sebuah kabupaten di Provinsi Jawa Barat, dengan Ibukota Parigi. Kabupaten ini berbatasan dengan kabupaten Ciamis dan kota Banjar di sebelah utara, kabupaten Cilacap disebelah timur, Samudera Indonesia disebelah selatan, serta kabupaten Tasikmalaya di sebelah barat. Berdasarkan konteks tata ruang nasional yang tertuang dalam Peraturan Pemerintah Nomor 47 tahun 1997 tentang Rencana Tata Ruang Wilayah Nasional (RTRWN), disebutkan bahwa kawasan Pangandaran dan sekitarnya merupakan salah satu kawasan andalan yang ada di Jawa Barat.

Dalam meningkatkan kunjungan wisatawan pantai Pangandaran maka diperlukan bauran pemasaran kepariwisataan yang handal, mengingat pemasaran pariwisata sifatnya cukup kompleks, hal ini disebabkan produk yang dipasarkan berupa jasa, sehingga sangat terikat dengan supplier yang menghasilkannya, instansi, organisasi atau lembaga pariwisata yang mengelolanya. Memasarkan produk pariwisata perlu adanya koordinasi serta kerjasama yang sinergis antara organisasi/lembaga yang bertanggung jawab dengan semua pihak yang terkait pada kegiatan pariwisata.

Pihak pengelola dan pihak terkait dalam mengelola Pantai Pangandaran harus mempunyai komitmen yang jelas, SDM yang memiliki kompetensi sesuai bidangnya, manajemen perlu dilaksanakan secara terpadu dan terarah, berdasarkan hal ini jika dilaksanakan secara optimal, maka akan meningkatnya wisatawan yang berkunjung ke pantai Pangandaran.

Menurut pendapat Yoeti (2005:151), "keberhasilan suatu program pemasaran dalam bidang pemasaran pariwisata sangat ditentukan oleh faktor kesamaan pandangan terhadap pariwisata bagi pembangunan daerah, karena itu sebelum program pemasaran dilaksanakan harus ada komitmen dari semua unsur terkait bahwa pariwisata merupakan sektor ekonomi yang bersifat quick yielding dan merupakan agent of development bagi daerah itu".

Melihat potensi kekayaan alam yang dimiliki oleh wisata Pantai Pangandaran, potensi ini perlu dipelihara dan dikembangakan secara baik, salah satunya melalui implementasi kajian bauran pemasaran kepariwisataan ini menjadi faktor penting sebagai upaya dalam meningkatkan kunjungan wisatawan, fakta lain yang ditemukan perkembangan pariwisata di Pangandaran kurang menggembirakan, perkembangannya dinilai masih lambat dari tahun ke tahun. Perkembangan berdasarkan tiket masuk kunjungan wisatawan selama 4 tahun terakhir terlihat sebagai berikut:

\section{Tabel 1}

Kunjungan wisatawan di Pangandaran (Tahun 2011 -2016)

\begin{tabular}{|c|c|l|l|l|}
\hline Tahun & $\begin{array}{c}\text { Wisnu } \\
\text { (Orang) }\end{array}$ & $\begin{array}{c}\text { Wisman } \\
\text { (Orang) }\end{array}$ & $\begin{array}{c}\text { Total } \\
\text { (Orang) }\end{array}$ & $\begin{array}{l}\text { Tren } \\
\text { Kenaikan/ } \\
\text { Penurunan }\end{array}$ \\
\hline 2013 & 1.442 .974 & 10.050 & 1.453 .024 & 0 \\
\hline 2014 & 1.393 .713 & 13.086 & 1.406 .799 & $3,181 \%$ \\
\hline 2015 & 2.442 .413 & 16.515 & 2.458 .928 & $74,78 \%$ \\
\hline 2016 & 1.977 .614 & 10.776 & 1.988 .390 & $19,14 \%$ \\
\hline
\end{tabular}

Sumber: Dinas Kebudayaan \& Pariwisata Kab Pangandaran

Data yang disajikan dalam tabel di atas menunjukkan adanya kenaikan dan penurunan jumlah kunjungan wisatawan, di mana periode 2013-2014 sebesar 3,181\% terjadi penurunan 
kunjungan. Tahun 2014 - 2015 sebesar 74,78\% terjadi kenaikan, Tahun 2015 - 2016 sebesar $19,14 \%$ terjadi penurunan kunjungan. Wistawan Mancanegara (Wisman) terjadi penurunan cukup signifikan dari tahun 2015-2016. Melihat kondisi di atas perlu dilakukan langkah-langkah strategis yang dapat mendorong peningkatan kunjungan wisata di kawasan Pangandaran.

Industri pariwisata (intangible) sangat berbeda dengan Industri manufaktur, maka pemasarannya cukup berbeda sehingga harus memperhatikan strategi pemasaran, yaitu proses segmentasi, posisi dan bauran pemasaran. Industri pariwisata memiliki tiga produk utama, yaitu atraksi wisata (festival, pantai dan lainnya), jasa wisata (hotel, restoran dan lainnya), dan angkutan wisata (kapal, mobil dan lainnya). Ketiga produk ini saling terkait satu sama lainnya dan ketiganya harus ada agar suatu aktivitas bisa dikatakan sebagai pariwisata. Ketiga jenis produk di atas ditujukan untuk memenuhi tiga kebutuhan konsumen ketika berwisata yaitu, kebutuhan motif berwisata, kebutuhan selama berwisata dan kebutuhan untuk mencapai lokasi wisata.

Soekadijo (2005) mengungkapkan bahwa industri pariwisata memiliki perbedaan bila dibandingkan dengan industri lainnya:

1. Produk pariwisata tidak dapat dibawa ke tempat wisatawan, produk wisata harus dinikmati di tempat dimana produk itu tersedia.

2. Wujud dari produk pariwisata akhirnya ditentukan oleh konsumen itu sendiri, yaitu wisatawan. Bagaimana bentuk-bentuk komponen produk wisata itu akhirnya tersusun menjadi suatu produk pariwisata yang utuh, pada dasarnya wisatawan yang menyusunnya.

3. Apa yang diperoleh konsumen setelah "mengkonsumsi" produk pariwisata adalah pengalaman,

Implementasi bauran pemasaran kepariwisataan menjadi bagian terpenting dalam peningkatkan kunjungan wisatawan, karena lebih mengarah pada pembentukan keunggulan yang berupa keistimewaan dari objek wisata sehingga mampu menimbulkan daya tarik yang tinggi dengan daya saing yang tinggi juga, sehingga perlu dilaksanakan secara optimal.

Berdasarkan hasil di lapangan menunjukkan bahwa bauran pemasaran kepariwisataan pantai Pangandaran sebagai berikut: Produk yang ditawarkan belum tertata dengan baik. Harga tiket cukup terjangkau bagi wisatawan, karena relatif murah, tetapi kenaikan wisatawan yang datang masih rendah. Saluran pendistribusian menuju kawasan mudah dan baik, namun disini perlu adanya tour guide yang bisa memandu dengan baik. Pihak-pihat terkait wisata Pangandaran kurang memahami prinsip pesona wisata, menyiapkan sajian pelayanan kurang profesional, fisik wisata pantai kurang terkonsep dengan baik. Cukup kompleksnya permasalahan yang dihadapi apalagi dengan diberlakukanyya otonomi daerah, kelemahan sektor pariwisata cukup dirasakan sehingga bisa menghambat terhadap pengembangan sektor pariwisata.

Berdasarkan pada beberapa aspek yang diamati, maka wisata pantai Pangandaran dalam mengimplementasikan bauran pemasaran kepariwisataan belum dilaksanakan secara optimal, untuk memperkuat hasil penelitian ini didukung oleh penelitian sebelumnya Yunita (2016), Wahyundari, Sudiarto, Eka Madewi (2015).

Tujuan yang ingin dicapai dari penelitian ini untuk mengetahui dan mengkaji:

$\begin{array}{lcr}\text { 1. Implementasi bauran } & \begin{array}{r}\text { pemasaran } \\ \text { kepariwisataan }\end{array} \\ \text { dalam } & \text { meningkatkan }\end{array}$ wisatawan,

2. Kondisi kunjungan wisatawan

3. Faktor-faktor penghambat implementasi bauran pemasaran kepariwisataan dalam upaya peningkatan kunjungan wisatawan,

4. Strategi bauran pemasaran kepariwisataan dapat meningkatkan kunjungan wisata di kawasan wisata Pantai Pangandaran,

5. Optimalisasi kunjungan wisata Pangandaran.

\section{KAJIAN PUSTAKA}

Menurut Kotler (2002:18), "bauran pemasaran adalah "seperangkat alat pemasaran yang digunakan perusahaan untuk terus menerus mencapai tujuan pemasaran di pasar sasaran". Menurut Kotler dan Amstrong (2012:62), "dalam bauran pemasaran terdapat seperangkat alat pemasaran yang dikenal dalam istilah $4 \mathrm{P}$, yaitu produk, harga, tempat, atau saluran distribusi, dan promosi, sedangkan dalam pemasaran jasa memiliki beberapa alat pemasaran tambahan seperti orang, fasilitas fisik dan proses, sehingga dikenal dengan istilah 7P, yaitu:

1. Produk, adalah mengelola unsur produk termasuk perencanaan dan pengembangan produk atau jasa yang tepat untuk 
dipasarkan dengan mengubah produk atau jasa yang ada dengan menambah dan mengambil tindakan yang lain yang mempengaruhi bermacam-macam produk atau jasa.

2. Harga adalah suatu sistem manajemen perusahaan yang akan menentukan harga dasar yang tepat bagi produk atau jasa dan harus menentukan strategi yang menyangkut potongan harga, pembayaran ongkos angkut dan berbagi variabel yang bersangkutan.

3. Distribusi, yakni memilih dan mengelola saluran perdagangan yang dipakai untuk menyalurkan produk atau jasa dan juga untuk melayani pasar sasaran, serta mengembangkan sistem distribusi untuk pengiriman dan perniagaan produk secara fisik.

4. Promosi, adalah suatu unsur yang digunakan untuk memberitahukan dan membujuk pasar tentang produk atau jasa yang baru pada perusahaan melalui iklan, penjualan pribadi, promosi, penjualan, maupun publikasi.

5. Sarana fisik, merupakan hal nyata yang turut mempengaruhi keputusan konsumen untuk membeli dan menggunakan produk atau jasa yang ditawarkan.

6. Orang adalah semua pelaku yang memainkan peranan penting dalam penyajian jasa sehingga dapat mempengaruhi persepsi pembeli.

7. Proses adalah semua prosedur aktual mekanisme, dan aliran aktivitas yang digunakan untuk menyampaikan jasa.

Margenroth dalam Yoeti (1996:17), "pariwisata adalah lalu lintas orang-orang yang meninggalkan tempat tinggalnya untuk sementara waktu, untuk berpesiar ke tempat lain, sematamata sebagai konsumen dari buah hasil perekonomian dan kebudayaan guna memenuhi kebutuhan hidup dan kebudayaan atau keinginan yang beranekaragam dari pribadinya".

Diperkuat pendapat Kodhyat (1983:4), "Pariwisata merupakan perjalanan dari satu tempat ke tempat yang lain, bersifat sementara, dilakukan perseorangan maupun kelompok, sebagai usaha mencari keseimbangan atau keserasian dan kebahagiaan dengan lingkungan hidup dalam dimensi sosial, budaya, alam dan ilmu".

Produk bagian dari bauran pemasaran kepariwisataan, dalam hal ini produk wisata, menurut Suwantoro (2004) "produk wisata adalah "keseluruhan pelayanan yang diperoleh dan dirasakan atau dinikmati wisatawan semenjak ia meninggalkan tempat tinggalnya, sampai ke daerah tujuan wisata yang telah dipilihnya dan kembali ke rumah di mana ia berangkat semula."

Menurut Wahab (2003) "ada dual hal yang dapat ditawarkan kepada wisatawan sehingga menarik wisatawan untuk berkunjung kesuatu daerah tujuan wisata, dimana dua hal tersebut dapat berupa alamiah atau buatan manusia yaitu:

a. Sumber-sumber alam

1. Iklim : udara lembut, bersinar matahari, kering dan basah

2. Tata letak tanah dan pemandangan alam: dataran, pegunungan yang berpanorama indah, danau, sungai, pantai, bentuk-bentuk yang unik, pemandangan yang indah, air terjun, daerah gunung berapi, gua dan lainlain.

3. Unsur rimba: hutan-hutan lebat, pohon-pohon langka dan sebagainya

4. Flora dan fuana: tumbuhan aneh, barangbarang beragam jenis dan warna, kemungkinan memancing, berburu dan bersafari foto binatang buas, taman nasional dan taman nasional dan taman suaka binatang dan sebagainya.

5. Pusat-pusat kesehatan: sumber air mineral alam, kolam lumpur berkhasiat untuk mandi, sumber air panas alam untuk penyembuhan penyakit dan sebagainya.

b. Hasil karya manusia yang ditawarkan".

Dalam pengembangan suatu daerah sebagai tempat tujuan wisata harus disesuaikan dengan keinginan wisatawan yang datang ke tempat tersebut, dan obyek wisata yang dituju harus jelas, menurut SK. MENPARPOSTEL No.: KM. 98/PW.102/MPPT-87, Obyek Wisata adalah semua tempat atau keadaan alam yang memiliki sumber daya wisata yang dibangun dan dikembangkan sehingga mempunyai daya tarik dan diusahakan sebagai tempat yang dikunjungi wisatawan.

\section{METODE PENELITIAN}

Metode yang digunakan dalam penelitian metode kualitatif, data dikumpulkan melalui observasi, wawancara mendalam, dan dokumentasi. Teknik yang digunakan dalam metode kualitatif teknik triangulasi, di mana hasil dari salah satu wawancara dikonfirmasikan kepada pihak lain, agar menghasilkan kesimpulan terbaik dan dapat memperkuat argumentasi peneliti. Wawancara 
dilakukan dengan pihak internal dan expert judgment sebagai berikut:

\section{Tabel 2}

Pihak Internal dan Expert Judgment

\begin{tabular}{|l|l|}
\hline \multicolumn{1}{|c|}{ Nama } & \multicolumn{1}{|c|}{ Jabatan / Pengalaman } \\
\hline $\begin{array}{l}\text { Dr. Liga } \\
\text { Suryadana }\end{array}$ & $\begin{array}{l}\text { Tim Advisor Pengembangan } \\
\text { Pariwisata. Dinas } \\
\text { Kebudayaan dan Pariwisata } \\
\text { Provinsi Jawa Barat. }\end{array}$ \\
\hline $\begin{array}{l}\text { Dr. Emron } \\
\text { Edison }\end{array}$ & $\begin{array}{l}\text { Kepala SPI Perusahaan PD. } \\
\text { Jawi Jawa Barat (2012-2016), } \\
\text { Ketua Prodi Manajemen } \\
\text { Pariwasata STIEPAR }\end{array}$ \\
\hline $\begin{array}{l}\text { Nunung } \\
\text { Sobana }\end{array}$ & $\begin{array}{l}\text { Kepala Dinas Pariwisata } \\
\text { Jawa Barat } \\
\text { Periode 2013-2016 }\end{array}$ \\
\hline Supratman & $\begin{array}{l}\text { Ketua Presidium } \\
\text { Pangandaran }\end{array}$ \\
\hline
\end{tabular}

\section{HASIL DAN PEMBAHASAN}

\section{A. Implementasi Bauran Pemasaran Kepariwisataan Dalam Upaya Peningkatan Kunjungan Wisatawan}

Dari hasil penelitian ada beberapa bagian yang saling berhubungan satu sama lain, sebagai berikut:

\section{Produk (Product)}

Kawasan Pangandaran merupakan salah satu Growth Center Jawa Barat bagian Selatan dengan berbasis pada sektor pariwisata. Salah satu favoritnya adalah pantai barat merupakan pantai berpasir yang sering dijadikan sebagai tempat berbagai aktivitas seperti berlarian, voli pantai, futsal, berenang, berjemur termasuk berselancar. Pantai timur area pantai langsung berbatasan dengan laut yang terhubung dengan dermaga. Pantai Pasir Putih,sesuai namanya, pantai ini memiliki pasir berwarna putih. Hal ini berbeda dari umumnya kawasan pantai yang lain di sekitar Pangandaran yang berpasir kecokelatan. Namun demikian berdasarkan dari hasil pengamatan bahwa kondisi di wisata pantai Pangandaran masih banyaknya Pedagang Kaki Lima (PKL) yang menghalangi destinasi wisata dan kurang terjaganya kebersihan dan keindahan, hal ini disebakan pengelola wisata pantai Pangandaran belum memiliki komitmen yang jelas, menurut pendapat pihak Internal dalam melaksanakan pekerjaan harus sejalan dengan SOP yang berlaku di wisata Pantai Pangandaran dan ini diperkuat juga oleh pendapat expert judgment, komitmen ini belum dipegang teguh oleh para pelaku usaha, sehingga kawasan tersebut kurang tertata rapi dan tingkat kebersihan yang kurang terjaga.

2. Harga (price).

Harga tiket untuk masuk dikawasan pantai Pangandaran relatif murah, namun belum ada sistem dalam kunjungan wisata secara akurat, menurut pendapat pihak internal diperlukan adanya penentuan harga tiket yang jelas dan sesuai standar, sehingga tidak ada persepsi mahal dari wisatawan, dan hal ini diperkuat dengan pendapat Internal dan expert judgment "database tentang wisatawan yang datang ke pantai Pangandaran saat ini belum akurat, hanya berdasarkan bukti masuk tiket, sehingga diperlukan monitor yang konsisten tentang jumlah pengunjung, dengan demikian pengelola bisa mempersiapkan berbagai kebutuhan, fasilitas wisata yang diinginkan oleh para wisatawan.

3. Bauran Promosi (promotion).

Bauran promosi yang dilaksanakan masih mengandalkan dari pengunjung tradisional, hal ini disebabkan pengelola belum begitu paham tentang pentingnya promosi, pendapat pihak internal dan expert judgment, "sebagian pengelola pariwisata di Pangandaran belum menyadari pentingnya promosi tentang kegiatan parawisata, dan, kita ketahui promosi itu penting, bagaimanapun destinasi itu akan memengaruhi jumlah wisatawan, dan promosi berperan untuk meningkatkan citra destinasi dimata pasar, Jika promosi ini kurang dikelola secara profesional, maka citra Pangandaran di peta parawisata masih ketinggalan dibandingkan destinasi yang sudah terkenal, padahal dari segi potensi pantai Pangandaran memiliki keindahan dan keunikan yang luar biasa"

3. Distribusi (place)

Saluran distribusi yang dilaksanakan menuju kawasan wisata pantai Pangandaran kurang memadai dan kondisi rusak, disebabkan saluran pendistribusian dalam akses menuju kawasan belum begitu baik, menurut pihak internal dan expert judgment, mengatakan bahwa,'distribusi dalam konteks pencapaian distinasi, saat ini masih relatif belum baik karena jarak tempuh menuju kawasan pantai Pangandaran cukup jauh, terutama wisatawan yang datang dari Jakarta. Seringkali mendapat hambatan karena kemacetan, jalan sempit, berkelok-kelok dan berlubang, sehingga wisatawan merasa kesulitan." 
5. Karyawan (People).

Pengelola kawasan pantai Pangandaran kurang memahami bauran pemasaran kepariwisataan, ini disebabkan pengelola wisata pantai Pangandaran belum diberikan pelatihan-pelatihan yang lebih konperehensif dalam rangka peningkatan kinerja, sesuai dengan pendapat Internal dan expert judgment mengatakan bahwa, pihak pengelola perlu mengikuti berbagai macam pelatihan yang terkait dengan pelayanan terhadap para wisatawan, pelatihan yang terkait dengan keamanan, bagaimana cara menanggulangi seperti adanya bencana tsunami, pelatihan ini diberikan juga kepada masyarakat sekitar untuk membuat barang-barang kerajinan yang menjadi oleh-oleh atau kenang-kenangan bagi para wisatawan. Pengelola akan mengetahui bagaimana cara mengatasi kebersihan dan kesehatan, apalagi di Pantai Pangandaram terkenal dengan nyamuk Aides Agepty. Dengan menjaga Sapta Pesona di wilayah pantai Pangandaran, maka dapat menjadi daya tarik para wisatawan dan dapat meningkatkan kinerja pengelola itu sendiri.

6. Proses (Process)

Bauran pemasaran dari segi proses, kunjungan wisatawan dibiarkan untuk menikmati pantai tanpa arahan yang jelas, berdasarkan hasil pengamatan bahwa wisatawan pantai Pangandaran perlu adanya tour guide yang terkoordinir, sehingga para pengunjung akan lebih tertib, menurut pendapat pihak internal dan expert judgment: tour guide sangat diperlukan karena untuk mempermudah para wisatawan yang datang berwisata ke pantai Pangandaran, agar tidak terjadi wisatawan yang nyasar untuk masuk ke wilayah-wilayah lainnya yang berada disekitar wisata pantai Pangandaran.

7. Keadaan fisik (physical evidence)

"Keadaan fisik wisata pantai Pangandaran kurang terpeliharanya kebersihan dan keindahan, sarana dan prasarana masih kurang, berdasarkan hasil pengamatan di pantai Pangandaran zona wisata pantai Pangandaran perlu ditata sesuai dengan pendapat pihak internal dan expert judgment "zona wisata pantai Pangandaran jelas perlu karena penting. Zona wisata Pantai Pangandaran tidak terhalangi oleh para UKM apabila dibuat rencana terarah dan terukur, sehingga peran UKM tetap berjalan baik, dan indahnya pantai Pangandaran akan menjadi daya tarik bagi para wisatawan.

\section{B. Kondisi kunjungan wisata Pantai Pangandaran}

Berdasarkan hasil pengamatan menunjukkan bahwa:

1. Rendahnya kunjungan wisatawan, disebabkan kemampuan pengelola wisata pantai Pangandaran dalam pemasaran masih kurang, menurut pihak internal: bauran pemasaran kepariwisataan dalam meningkatan kunjungan wisatawan lebih dioptimalkan, mengingat potensi kita sangat kaya dengan wisata alam pantai maupun wisata alam pegunungan, sehingga ini bisa dijadikan daya jual bahkan telah ditemukan ada sekitar 1.000 goa, pasca Tsunami di Pangandaran itu sudah dibuat dokumen perencanaan dari mulai penataan peningkatan kapasitas masyarakat sampai dengan beberapa peningkatan pembenahan beberapa destinasi wisata, pendapat expert judgment mengatakan bahwa, "apabila dilihat dari kemampuan pegawai terhadap pemasaran masih rendah, masih minim dan masih tradisional dalam melakukan promosi, sehingga jelas informasi kurang cepat diterima oleh para turism, brosur yang begitu sederhana harusnya untuk meningkatkan wisatawan, program pemasaran harus lebih ditingkatkan, misalnya dengan membuat website, informasi di sosial media, pelayanan teknis tentang kepariwisataan, facebook, twiter, instragram dan lainnya yang bisa memberikan informasi lengkap tentang pantai Pangandaran".

2. Ruang gerak bagi para pelaku UKM masih rendah, menurut pihak internal dan expert judgment: memberikan ruang gerak bagi para pelaku UKM dan sektor informal yang terlibat dalam penyediaan pelayanan melalui dinas"., bagi wisatawan yang datang bisa membeli oleh-oleh sebagai ciri khas dari pantai Pangandaran hasil usaha skala UKM

\section{Menghilangkan Faktor-Faktor Penghambat Implementasi Bauran Pemasaran Kepariwistaan Dalam Upaya Peningkatan Kunjungan Wisatawan.}

Berdasarkan hasil pengamatan wisata pantai Pangandaran yang menjadi faktor-faktor penghambat implementasi bauran pemasaran kepariwisataan dalam meningkatkan kunjungan 
wisatawan sebagai berikut:

1. Terjadinya perbedaan harga, padahal tiket untuk masuk relatif murah, hal ini disebabkan tidak tegasnya dalam perhitungan pengunjung, dan tidak ada standar potongan harga, penerapan bauran pemasaran dilihat dari segi kompetensi masih rendah, pegawai masih belum memahami bauran pemasaran kepariwisataan secara sistematik, menurut pendapat pihak internal dan expert judgment pengelola kawasan wisata pantai Pangandaran kurang memperhatikan fasilitas wisata yang masih tertinggal seperti jalan yang rusak, kebersihan yang kurang, sarana dan prasarana yang belum memadai sehingga masih tertinggal dengan tempat wisata yang lain. Di samping itu kemampuan pegawai terhadap pemasaran masih minim dan masih tradisional dalam melakukan promosi, sehingga jelas informasi kurang cepat diterima oleh para wisatawan, brosur masih sederhana, program pemasaran harus lebih ditingkatkan, misalnya website lebih digunakan, informasi sosial media, pelayanan teknis tentang usaha kepariwisataan, facebook, twiter, instragram dan lainnya yang bisa memberikan informasi yang lengkap tentang pantai Pangandaran".

2. Fasilitas yang disediakan masih kurang, terutama dibidang sarana dan prasarana, dan belum memprioritaskan anggaran untuk tujuan fasilitas, "Fasilitas wisata pantai Pangandaran masih relatif tertinggal dibanding dengan wisata pantai di luar negeri, hal ini disebabkan kurangnya pengelolaan yang optimal, fasilitas sarana dan prasarana perlu lebih ditingkatkan. Karena dengan meningkatnya wisatawan yang datang ke pantai Pangandaran, dari retribusi akan meningkatkan Pendapatan Asli Daerah (PAD), karena tidak hanya pajak saja, tetapi harus dibantu dengan restribusi pendapatan yang diperoleh dari penjualan tiket, tetapi walaupun seperti itu, pajak pun perlu untuk dioptimalkan sehingga Pendapatan Asli Daerah (PAD) akan meningkat".

\section{Strategi bauran pemasaran dapat} meningkatkan kunjungan wisata di kawasan Wisata Pantai Pangandaran

Berdasarkan hasil pengamatan bahwa peningkatan strategi bauran pemasaran dapat meningkatkan kunjungan wisatawan, ada beberapa hal yang perlu diperbaiki, sebagai berikut:

1. Mengindentifikasi kebutuhan, keinginan dan kepuasan wisatawan secara efektif dan efesien serta menjaga loyalitas

2. Strategi bauran pemasaran harus didukung kualitas pelayanan yang baik, harapan wisatawan dibentuk oleh pengalaman masa lalunya, pembicaraan mulut ke mulut serta promosi yang dilakukan kemudian dibandingkan, menurut pendapat pihak internal dan expert judgment. Sarana dan prasarana perlu adanya penambahan berbagai fasilitas wisata, dengan menambah berbagai fasilitas wisata, objek wisata Pangandaran bisa menarik wisatawan dari luar, misalnya dengan upaya lain, misalnya menambah usaha dibidang transportasi, biro perjalanan, hiburan atraksi kesenian daerah yang dapat dijadikan potensi Pendapatan Asli Daerah (PAD), yang didukung oleh wisata yang datang ke pantai Pangandaran.

3. Banyaknya pintu masuk, dan sebagian perlu terawasi, menurut pendapat pihak internal dan expert judgment untuk mengurangi tingkat kebocoran, terutama dibagian restribusi, tiket masuk, terlalu banyak akses pintu yang menuju pantai Pangandaran, maka harus dibuat konsep, yaitu dengan dibuatnya pintu masuk dari berbagai lokasi, tidak hanya mengandalkan pintu utama saja, dan yang menjadi tingkat kesulitan karena wisata pantai Pangandaran pintu masuknya berbaur dengan pintu masuk masyarakat, hal ini harus bisa dipisahkan untuk pintu masuk mana yang kearah pantai Pangandaran, mana yang ke arah masyarakat, misalnnya, pintu masuk untuk masyarakat melalui tengah, sedangkan pintu masuk ke pantai Pangandaran dari belakang atau lainnya, yang bisa mengurangi tingkat kebocoran".

4. Pelayanan terhadap wisata yang menginap masih rendah, menurut pihak internal dan expert judgment, Service belum optimal, pengelola hotel belum ada pelayanan yang baik sehingga tamu kurang puas, maka dalam hal ini perlu adanya upaya pemerintah untuk melakukan pelatihan manajerial kepada pemilik hotel, agar tamu yang nginap lama dan betah, ini akan menambah income lainnnya.

5. Kebersihan dan fasilitas bermain masih kurang di wisata pantai Pangadaran, ini menyebabkan kurang kenyamanan bagi 
pengunjung, dan tidak betah lama-lama untuk berkunjung ke wisata pantai pangandaran, menurut pihak internal dan expert judgment, agar tingkat kebersihan meningkat, yaitu tingkat kebersihan pantai Pangandaran lebih di optimalkan dengan melihat pantai di luar negeri, misalnya dengan penataan fasilitas bermain, penghijauan, sehingga terbangunnya pantai yang indah dan sejuk.

6. Sarana dan prasarana di pantai Pangandaran masih relatif kurang, sehingga berpengaruh pada Pendapatan Asli Daerah, menurut pihak internal dan expert judgment mengatakan bahwa "Sarana dan prasarana harus lebih diperhatikan, misalnya pembuangan air yang tidak kemana-mana, ada sarana ibadah yang bersih, sanitasi yang hygiene, hotel yang indah, bersih, aman sehingga para wisatawan betah untuk menginap di hotel, dan dengan senangnya dia berlama lama untuk berekeasi di pantai Pangandaran, parkir dibuat lebih memadai, sehingga keamanan terjaga".

7. Promosi belum maksimal, bisa dikerjasamakan dengan pihak lain untuk meningkatkan promosi dengan cara iklan, leaflat, media sosial, internet, media elektronik dan pihak biro perjalan yang bertaraf international, menurut pihak internal dan expert judgment, mengatakan bahwa promosi secara nasional maupun internasional sangat efektif untuk meningkatkan kunjungan wisata

\section{E. Optimalisasi kunjungan wisata Pangandaran}

Berdasarkan hasil pengamatan belum optimalnya kunjungan wisatawan yang datang ke Pantai Pangandaran disebabkan beberapa faktor:

1. Kerjasama dengan pihak lain melalui promosi belum begitu dipromosikan ke mancanegara, sehingga berpengaruh terhadap kunjungan wisatawan, menurut pihak internal dan expert judgment, promosi penting, tanpa promosi bagaimana bisa menggiring wisata yang datang ke pantai Pangandaran, promosi pencitraan bukan untuk pencitraan saja tetapi harus bergeser ke promosi penjualan, misalnya: ada tingkat promosi yang dibiayai oleh pihak Pangandaran untuk wisatawan asing, seperti: Singapura, Malaysia, Thailand, Tiongkok, dengan dibiayai oleh Pemerintah Daerah Kabupaten Pangandaran, inilah yang bisa meningkatkan promosi ke mancanegara.
2. Penataan Pedagang Kaki Lima kurang tertata dengan baik, menurut pihak internal dan expert judgment jumlah tiket yang masuk akan optimal, jika tertata rapi di kawasan pantai Pangandaran akan banyaknya wisatawan yang datang yang berpengaruh pada Peningkatan Angkatan Daerah (PAD)

3. Hasil laut, kerajinan, pakaian bernuansa pantai dan sebagainya belum terkoordinir dengan baik dan perkembangan inovasi yang kurang, padahal wisata pantai Pangandaran bisa menghasilkan produk yang berkualitas, yaitu harus dengan cara profesional, misalnya, untuk menarik wisatawan, kerajinan dibuat profesional, buah tangan yang berkualitas, souvenir yang menarik, dibuat packaging yang baik dan berkualitas, sehingga para wisatawan bisa membeli oleh-oleh dengan kemasan dan kualitas yang baik, selain pengunjung meningkat juga dapat menunjang kepada meningkatnya perekonomian masyarakat.

\section{KESIMPULAN DAN REKOMENDASI}

Hasil penelitian mengenai implementasi bauran pemasaran kepariwisataan dalam upaya peningkatan kunjungan wisatawan di Pantai Pangandaran dari segi produk, harus ada komitmen yang jelas dengan pihak-pihak terkait dan komitmen harus dibangun untuk mencapai tujuan, harga, sudah relatif murah, namun sistem "database" harus dibuat akurat, ter update, SDM harus teruji kompetensinya, dan sistem tiket satu arah sehingga akan lebih termonitor, promosi harus dilakukan secara profesional dan berkesinambungan dengan didukung produk/jasa yang ditawarkan cukup menarik., pendistribusian untuk wisatawan lebih dibenahi, karyawan perlu diberikan pelatihan-pelatihan dalam mengelola pantai Pangandaran sesuai dengan tanggung jawab dan pekerjaannya, kunjungan wisatawan dibiarkan untuk menikmati pantai tanpa arahan yang jelas, perlu ada tour guide yang terkoordinir, sehingga para pengunjung akan lebih tertib, manajemen harus dilaksanakan secara terpadu dan terarah, sarana dan prasarana yang baik, media sosial yang lengkap yang bisa menarik para wisatawan untuk datang ke wisata pantai Pangandaran. 
DAFTAR PUSTAKA

Kodhyat, H, 1983, Sejarah Pariwisata dan Perkembangannya di Indonesia, Jakarta:PT. Gramedia Pustaka Utama.

Kotler , Philip and Gary Amstrong, 2012, Prinsip-Prinsip Pemasaran, Ed.ke-13, Jilid 1, Jakarta:Erlangga

Kotler, Philip, 2002, Manajemen Pemasaran, Ed. Millenium, Jilid 2, Jakarta:PT. Prenhallindo.

Soekadijo, R.G 2005, Anatomi Pariwisata memahami Pariwisata Sebagai Systematic Linkage, Jakarta:PT. Gramedia Pustaka Utama

Suwantoro, Gamal (2004:48), Dasar-dasar Pariwisat, Yogyakarta : Penerbit Andi

Wahab, Salah, 2003, Manajemen Kepariwisataan, Jakarta:PT. Pradaya Pramita

Wahyundari, Ni Wayan Vitha, Sudiarto, I

Nyoman, Eka Madewi, Ni Putu, Jurnal IPTA, Pengaruh Bauran Pemasaran Terhadap Kepuasan Wisatawan Mancanegara di Pantai Pandawa Kabupaten Bandung, Bali, Vol 3, No. 1 Tahun 2015.

Yoeti, Oka. A , 1996, Pengantar Ilmu Pariwisata, Bandung:Angkasa

Yoeti, Oka.A, 2005, Perencanaan Strategies Pemasaran Daerah Tujuan Wisata, Ed,ke-2, Jakarta:PT. Pradaya Pramita

Yunita, Henilia, Pengaruh Bauran Pemasaran Pariwisata Terhadap Keputusan untuk
Berkunjung, Vol 2, No. 2, November Tahun 2016.

UU RI .No.10 tahun 2009, tentang Kepariwisataan

Peraturan Pemerintah Nomor 47 tahun 1997 tentang Rencana Tata Ruang Wilayah Nasional (RTRWN),

SK. MENPARPOSTEL No.: KM. 98/PW.102/

MPPT-87, tentang Pariwisata

\section{Biodata Penulis}

\section{Penulis 1}

Imas Komariyah, lahir di Bandung, 10 Agustus 1968, Latar belakang Pendidikan S1 - STIE YPKP,Lulus Tahun 1992, S2 - STIAMI Jakarta, Lulus Tahun 2008, S3 - Universitas Pasundan, Lulus Februari 2015, Pekerjaan Dosen Universitas Wanita Internasional. Ketertarikan penelitian ingin mengkaji dan menganalisis tentang keadaan wisata Pantai Pangandaran, dan berharap dapat memberikan kontribusi yang berguna bagi pengembangan wisata Pantai Pangandaran khususnya juga untuk sebagai bahan kajian bagi wisata-wisata lainnya.

\section{Penulis 2}

Darmawan Megananda Sunandar, Lahir 4 Desember 1957, Sekolah Tinggi Manajemen Jakarta,1984, S2- Philipppine Cristian University 1989, S3- Universitas Pasundan, 2016, Pekerjaan: Dosen STIE Tridharma. 